- поглиблене вивчення вокальних творів з розділу «Дитяча музика», ескізне проходження творів пісенного репертуару для дошкільників;

- використання диригентської техніки 3 методикою роботи $з$ дитячим хоровим колективом: поєднання диригентського жесту із співом та грою на інструменті; перерозподіл уваги під час виконання із зверненням до дитячої аудиторії;

- поглиблене вивчення музичних творів різних жанрів, які внесені до програми музичного розвитку дошкільників;

- читання з листа, сольфеджування та транспонування пісень дитячого репертуару різних вікових груп із програми музичного розвитку дошкільників;

- гармонізація мелодій та підбір акомпанементу до пісенного репертуару (типи акомпанементу); активізація творчості студентів на основі елементів твору; гармонійний аналіз акомпанементу дитячих пісень;

- аналіз (образний, стильовий, структурний) вокальних та інструментальних творів 3 розділу «Слухання музики» програми «Я у світі» або іншій.

Отже, професійна спрямованість міжпредметних зв'язків у процесі навчання дозволяє не тільки активно впливати на особистість майбутнього музичного керівника, а й дозволяє удосконалювати його професійні знання, уміння, навички, поліпшувати фахову підготовку.

\title{
Література
}

1. Батышев С. Я. Научная организация учебно-воспитательного процесса / С. Я. Батышев. - [2-е изд.]. - М. : Высшая школа, 1975. - 448 с. 2. Педагогічний словник / редкол.: М. Д. Ярмаченко, І. А. Зязюн, В. М. Мадзігон, Н. Г. Ничкало, О. Я. Савченко, О. В. Сухомлинська та ін. ; за ред. М. Д. Ярмаченка. - К.: Педагогічна думка, 2000. - 516 с. 3. Тарарак Н. Г. Міжпредметні зв'язки вокально-хорових дисциплін у процесі фахової підготовки майбутнього вчителя музики / Н. Г. Тарарак // Теорія та методика навчання та виховання: [зб. наук. праць] / Харк. нац. пед. ун-т ім. Г.С. Сковороди. Харків: «ОВС», 2004. - Вип. 12. - С. 95-100. 4. Щолокова О. П. Основи професійної художньоестетичної підготовки майбутнього вчителя / О. П. Щолокова. - К.: ІЗМН, 1996. - 170 с.

Люба Скалич

\section{ТЕОРЕТИЧНІ АСПЕКТИ ПРОФЕСІЙНОЇ КОМПЕТЕНТНОСТІ МАЙБУТНЬОГО ВЧИТЕЛЯ}

Скалич Л. Й. Теоретичні аспекти професійної компетентності майбутнього вчителя.

У статті розкриваються загальні підходи до визначення поняття «компетентність» та «компетентнісний підхід» на сучасному етапі розвитку освіти в Україні, аналізуються проблеми підготовки вчителя до реалізації цього підходу в навчанні учнів.

Ключові слова: компетентнісний підхід, компетентність, компетенція, професійна компетентність, компетентнісно зорієнтований підхід.

Скалич Л. И. Теоретические аспекты профессиональной компетентности будущего учителя.

В статье раскрываются общие подходы к определению понятия «компетентность», а также «компетентностный подход» на современном этапе развития образования в Украине, анализируются проблемы подготовки учителя к внедрению этого подхода к обучению учеников.

Ключевые слова: компетентностный подход, компетентность, компетенция, профессиональная компетентность, компетентностно-ориентированный процесс.

Skalych L. J. Theoretical aspects of professional competency of future teacher.

General approaches to the definition of contents «competency» and "competency building approach» on the modern level of development of education in Ukraine are presented in the article. The problems of teacher training to the realization of this approach while teaching are also analysed.

Key words: competency building approach, competency, competence, professional competency, competency and orientated approach.

Сучасна педагогіка не обмежує змісту освіти лише формуванням знань та вмінь. Для того, щоб людина могла виконувати певний вид соціальної діяльності, необхідно, щоб вона знала ту галузь, у якій працюватиме, ті процеси, які там здійснюються, умови, у яких це відбувається, 
типові іï проблеми; володіла узагальненими способами діяльності в цій галузі; мала досвід творчого розв'язання проблем; мала стійкі ціннісні орієнтації, що дозволяють дотримуватися певного напрямку цієї діяльності; володіла загальними компетентностями стосовно самоорганізації в будь-якій діяльності, взаємодії з іншими людьми; мала бажання активно співдіяти в соціумі [1, с. 48].

Мета статmі - розкрити загальні підходи до визначення поняття компетентності та компетентнісного підходу на сучасному етапі розвитку освіти в Україні та зарубіжних країнах, проаналізувати проблеми підготовки вчителя до реалізації цього підходу в навчанні учнів.

Останнім часом з'явилася низка наукових праць, присвячених аспектам підготовки вчителів нового покоління. Серед них найбільшої уваги, на нашу думку, заслуговують дослідження О. Абдуліної, В. Андрущенка, Б. Грицюк, Н. Білокур, В. Бондаря, М. Вашуленка, Б. Гершунського, Ф. Гонобліна, В. Загвязінського, В. Кременя, Н. Кузьміної, О. Мороза, А. Піскунова, О. Савченко, Н. Бібік, О. Овчарук, О. Пометун, Р. Скульського В. Сластьоніна та ін., що розкривають основні тенденції, соціально-педагогічні механізми, специфіку підготовки фахівців педагогічної сфери діяльності. Науковцями визначено компоненти педагогічної діяльності вчителя, структуру, зміст і обсяг професійно-педагогічних умінь, необхідних йому для ефективної діяльності.

Компетентність майбутнього педагога визначає спектр його особистісних якостей: когнітивну, операційно-технологічну, мотиваційну, етичну, соціальну, рефлексивну, оцінну, світоглядну, поведінкову тощо.

Компетентнісно зорієнтований підхід - один із нових концептуальних орієнтирів, напрямів розвитку змісту освіти в Україні та розвинених країнах світу. Відомі міжнародні організації, що нині працюють у галузі освіти, останніми десятиліттями вивчають проблеми, пов'язані 3 появою компетентнісно зорієнтованої освіти, серед них - ЮНЕСКО, Рада Свропи тощо.

Компетентнісний підхід відповідає фундаментальним цілям освіти, сформульовано в документах ЮНЕСКО:

- навчити отримувати знання (вчити вчитися);

- навчити працювати і заробляти (навчання для праці);

- навчити жити (навчання для буття);

- навчити жити разом (навчання для спільного життя) [4, с. 12].

Запровадження компетентнісного підходу в освіті розвинених країн Європи у 80-ті роки $\mathrm{XX}$ ст. пов'язане з фіксацією експертами в цих країнах спрямованості освіти на переважне засвоєння системи знань, яка була традиційною й виправданою ще кілька десятиліть тому. На час експертизи вона вже не відповідала соціальному замовленню, яке мало виховання самостійних, ініціативних і відповідальних членів суспільства, здатних активно взаємодіяти у розв'язанні соціальних, виробничих та економічних завдань. Виявилось, що результати освіти не задовольняють вимоги суспільства i, насамперед, роботодавці. Зауважувалось, що більшість випускників навчальних закладів виявляються навченими, готовими до реалізації професійних обов'язків, розв'язання реальних професійних та життєвих проблем [7, с. 144].

Компетентність - стосовно структури змісту освіти, який побудовано за галузевим принципом, і в програмах - за предметним, - виводить метарівень, що в інтегрованому вигляді становить освітні результати, які досягаються не лише засобами освіти, але й соціальної взаємодії; як у міжособистісному, так і в інституційному культурному контексті. Таких результатів можна спрогнозувати безліч (у сфері когнітивній, діяльнісній, мотиваційній, соціальній). Як відомо 3 літератури, Дж. Равен побудував модель компетентностей із 143 елементів, що робить ії застосування проблематичним. Тому цілком слушно запроваджують поняття «ключові компетентності», які охоплюють найзагальніші складники - своєрідні «суперкомпетентності».

На думку О. Пометун, компетентність - це складна інтегрована характеристика особистості, під якою розуміють набір знань, умінь, навичок, ставлень, що надають змогу ефективно провадити діяльність або виконувати певні функції, забезпечуючи розв'язання проблем і досягнення певних стандартів у галузі професії або інших видів діяльності. Під поняттям «компетентнісний підхід в освіті» дослідниця розуміє спрямованість освітнього процесу на формування й розвиток основних базових і предметних компетентностей особистості.

Результатом такого процесу повинно бути формування загальної компетентності дитини, що $\epsilon$ сукупністю ключових компетентностей, інтегрованою характеристикою особистості [8, с. 18]. 
Саме тому сучасна педагогічна наука визначає певну систему компетентностей, яку набуває учень, опановуючи зміст освіти в навчально-виховному процесі загальноосвітнього навчального закладу. Ця система містить ключові, або надпредметні компетентності, які формуються під час засвоєння змісту всіх предметів і галузей освіти, і є найважливішими. Ключова компетентність може бути визначена як здатність людини здійснювати складні поліфункціональні, поліпредметні, культуродоцільні види діяльності й ефективно розв'язувати відповідні проблеми, їх формування $є$ загальним результатом засвоєння учнем усього змісту середньої освіти. Другий складник цієї системи - галузеві компетентності, які формуються в результаті опанування учнем змісту однієї галузі в усіх класах середньої школи. I, нарешті виокремлюються предметні компетентності, що набуваються учнем у процесі вивчення того чи того предмета в усіх класах середньої школи [8, с. 18].

Дослідник О. Овчарук узагальнила основні підходи міжнародних освітніх організацій до визначення компетентностей. Так, Міжнародна комісія Ради Європи розглядає поняття компетентності як загальні або ключові вміння, базові вміння, фундаментальні шляхи навчання, ключові кваліфікації, ключові уявлення. Компетентність, на думку експертів, передбачає спроможність особистості відповідати на індивідуальні та соціальні виклики, формувати комплекс ставлення цінностей, знань і навичок.

Таке визначення поняття компетентностей деякою мірою збігається з положеннями, що висловлюють українські педагоги, однак представники європейських педагогічних кіл виходять 3 особистісних і соціальних потреб, задоволенню яких мають сприяти компетентності [7, с. 295].

Отже, компетентність - це володіння людиною відповідною компетенцією (компетенціями), яка охоплює його особистісне ставлення до неї і до предмета діяльності.

У педагогічній діяльності необхідно розрізняти ці поняття, маючи на увазі під компетенцією наперед задану вимогу (норму) до освітньої підготовки майбутнього фахівця початкової ланки освіти, а під компетентністю - вже сформована його особистісна якість $\mathrm{i}$ мінімальний досвід стосовно діяльності в заданій галузі.

Компетентність передбачає мінімальний досвід володіння компетенцією, ії використання в практичній діяльності.

Сучасні науковці в галузі педагогіки виокремлюють у структурі професійної компетентності вчителя такі її складники: психолого-педагогічні знання; теоретико-практичні й методичні вміння; педагогічні вміння; педагогічні здібності.

Сутність теоретичної готовності вчителя до діяльності передбачає наявність у нього аналітичних, прогностичних, проективних умінь. Зміст практичної готовності вчителя виражається в зовнішніх уміннях, тобто в діях, які можна спостерігати. До них належать комунікативні (перцептивні, педагогічне спілкування, педагогічна техніка) й організаторські (мобілізаційні, інформаційні, розвивальні, орієнтаційні), здатність до практичного розв'язання завдань, що забезпечується уміннями й навичками педагога.

Узагальнюючи вищезазначене, можна зробити висновок, що вчителеві початкових класів важливо зосередити зусилля на:

- оволодінні учнями мистецтвом жити, технологіями життєвого успіху, вмінням жити і контактувати з батьками, рідними, вчителями, однолітками та іншими людьми;

- розвитку вміння управляти собою, ставити мету, визначати сенс життя, попереджувати і розв'язувати життєві конфлікти;

- стимулюванні процесу духовного самовдосконалення, самовиховання, потреби допомагати іншим людям, оволодіння механізмами саморегуляції.

Окреслені теоретичні положення можуть стати конструктом для розроблення концепції розвитку компетентності учнів в умовах середньої школи.

У статті розглянуто сучасні наукові підходи до розвитку сутності компетентностей та компетентнісного підходу в освіті, а також проблему підготовки вчителя до реалізації компетентнісного підходу в навчанні учнів. Подальші наукові пошуки в цьому напрямку будуть стосуватися окремих видів компетентностей та шляхів їх формування в навчально-виховному процесі.

\section{Література}

1. Бібік Н. М. Компетентнісний підхід: рефлексивний аналіз застосування / Н. М. Бібік. - К. : К. І. С., 2004. - С. 47-53. 2. Боголюбов Л. П. Базовые социальные компетенции в курсе обществоведения // Боголюбов Л. П. Преподавание истории и обществоведения в школе. - 2002. - №9. - С. 22-24. 
3. Вашуленко М. С. Державний освітній стандарт 3 української мови (початкова ланка) / М. С. Вашуленко // Початкова школа. - 1997. - №3. - С. 44. 4. Декларація принципів толерантності // Національна комісія України у справах ЮНЕСКО. - К.,1995. - 14 с. 5. Зеер Э. Ф. Компетентностный подход к образованию / Э. Ф. Зеep // http: //www urorao.ru. 6. Кремень В. Г. Освіта і наука визначають авторитет держави / В. Г. Кремень // Історія в школах України. - 2002. - С. 2-4. 7. Овчарук О. В. Компетентності як ключ до оновлення змісту освіти / О. В. Овчарук // Стратегія реформування освіти в Україні: Рекомендації з освітньої політики. - К. : «К. І. С.», 2003. - 296 с. 8. Пометун О. І. Формування громадянської компетентності: погляд 3 позиції сучасної педагогічної науки / О. І. Пометун //Вісник програм шкільних обмінів. - 2005. - № 23. - С. 18. 9. Савченко О. Я. Удосконалення професійної підготовки майбутніх учителів початкових класів / О. Я. Савченко // Початкова школа. - 2001. - №7. - С. 3. 10. Словник іншомовних слів. - К. : Довіра, УНВЦ «Рідна мова», 2000. - 101 с. 11. Хуторской А. Ключевые компетенции как компонент личностно-ориентированной парадигмы образования / А. Хуторской // Народное образование. - 2003. - № 2. - С. 58-64.

Діна Тюріна

\section{ОБГРУНТУВАННЯ ТЕХНОЛОГІЇ ФОРМУВАННЯ ВМІНЬ МОДЕЛЮВАННЯ У СТУДЕНТІВ ВИЩИХ ЕКОНОМІЧНИХ НАВЧАЛЬНИХ ЗАКЛАДІВ У ПРОЦЕСІ САМОСТІЙНОЇ НАВЧАЛЬНОЇ ДІЯЛЬНОСТІ}

Тюріна Д. М. Обгрунтування технології формування вмінь моделювання у студентів вищих економічних навчальних закладів у процесі самостійної навчальної діяльності.

У статті запропоновано та обгрунтовано технологію формування вмінь моделювання у студентів вищих економічних навчальних закладів у процесі самостійної навчальної діяльності, що передбачає визначення груп умінь моделювання та полягає в реалізації мотиваційнопізнавального, тренувально-діяльнісного, рефлексивно-творчого етапів.

Ключові слова: моделювання, самостійна навчальна діяльність, технологія, уміння, студент, вищий економічний навчальний заклад.

Тюрина Д. Н. Обоснование технологии формирования умений моделирования у студентов высших экономических учебных заведений в процессе самостоятельной учебной деятельности.

В статье предложена и обоснована технология формирования умений моделирования у студентов высших экономических учебных заведений в процессе самостоятельной учебной деятельности, который предусматривает определение групп умений моделирования и заключается в реализации мотивационно-познавательного, тренировочно-деятельностного, рефлексивно-творческого этапов.

Ключевые слова: моделирование, самостоятельная учебная деятельность, технология, умение, студент, высшее экономическое учебное заведение.

Turina D. M. Justification technology skills formation modeling in students of higher economic education in the process of self-learning activities.

The author of the thesis is devoted to technology of modeling skills in students of higher economic education in the independent educational activity that involves identifying groups of skills and modeling is to implement motivational and educational, training-active, reflective and creative stages.

Key words: modeling, independent learning activities, technology, skills, student, higher economic institution.

На сучасному етапі розвитку української державни, інтеграції країни до світового співтовариства, активізації зовнішньоекономічних зв'язків значно зросла потреба у кваліфікованих фахівцях, спроможних якісно й творчо виконувати свої професійні обов'язки. Актуальності набуває завдання з підготовки кадрів нової формації в галузі економіки й фінансів. Аналіз Концепції розвитку економічної освіти України переконує, що в умовах складності та комплексності об'єктів, невизначеності та багатофакторності економічних процесів важливого значення для випускників економічних вищих навчальних закладів набуває сформованість умінь аналізувати й моделювати економічні ситуації в мікро- й макропредметному середовищі. 